\title{
Umbilical Granuloma
}

National Cancer Institute

\section{Source}

National Cancer Institute. Umbilical Granuloma. NCI Thesaurus. Code C112119.

Excessive granulation tissue at the base of the umbilicus after separation. 